\title{
Use of marijuana for medical purposes
}

\author{
Jarosław Pinkas', Piotr Jabłoński², Michal Kidawa², Waldemar Wierzba ${ }^{3}$ \\ ${ }^{1}$ Department of Healthcare Organizations and the Medical Jurisprudence, School of Public Health, Centre of \\ Postgraduate Medical Education, Warszawa, Poland \\ ${ }^{2}$ National Bureau for Drug Prevention, Warszawa, Poland \\ ${ }^{3}$ University of Humanities and Economics, Lodz, Poland
}

Pinkas J, Jabłoński P, Kidawa M, Wierzba W. Use of marijuana for medical purposes. Ann Agric Environ Med. 2016; 23(3): 525-528. doi: $10.5604 / 12321966.1219200$

\section{Abstract}

Cannabis is the most popular illicit drug on the European market. Over 16 million young Europeans have used it at least once in the last few years. The recent trends in the consumption of marihuana differ between countries. Some countries face an increase in the prevalence of cannabis use, including Poland, where the level cannabis use has been systematically increasing since the 1990's. According to a recent ESPAD study, 19\% of Polish adolescents aged 15-16 have used cannabis in the last year. Marihuana is also a leading substance when analyzing the data of seizures and crimes. The recent EMCDDA Annual report on the drug situation in Europe notes the increasing potency in cannabis available on the market. Some countries face an increasing number of emergencies caused by marihuana, which was unlikely to have happened previously. In almost all European countries there is an ongoing discussion about loosening marijuana laws or its complete legalization. There is also ongoing discussion on the use of marihuana in therapy as a medicine. Many scientific studies are being conducted in this field. Some of the results are promising; however, there is no well-designed human trial which would unequivocally confirm that medical cannabis is effective as a medicine, or more effective than other medicines on the market. The problem is that the debate on the medical use of marihuana becomes more ideological and less professional. The medical use of marihuana is strongly supported by organizations lobbying for the legalization of cannabis use. Research on the medical use of cannabis should be continued, as there are some promising results supporting therapy in different medical conditions. However, the use of cannabis as a medicine should be discussed only among professionals. If marihuana is to be used for medical purposes, the fact that it is the most popular illicit drug in Europe is irrelevant.

\section{Key words}

medical cannabis, public health, drug policy, public debate

\section{INTRODUCTION}

Marijuana on the Polish and European drug scene Prevalence. Marijuana is the most prevalent psychoactive substance in Europe. According to the European Monitoring Centre for Drugs and Drug Addiction (EMCDDA), 16.6 million young Europeans aged 15-34 (13.3\%) have used cannabis at least once in the last 12 months. Trends in the respective European countries vary. Among the countries which have been conducting population surveys since 2013, eight have reported rises in the prevalence of cannabis use, one reported a fall, and in four countries the trend was stable. Surveys in the countries where prevalence rates of cannabis use are relatively high, such as Germany, Spain and the United Kingdom, show that the trend has levelledoff. Increases in this area have been recorded in France as well as countries of low prevalence rates such as Finland, Sweden or Bulgaria. A substantial increase since 2011 (earliest data available) have been recorded in the Czech Republic (EMCDDA) [1].

In recent years, Poland has also seen a rise in the prevalence of cannabis use.

The latest edition of the nationwide questionnaire survey on the use of alcohol and drugs in school youth was undertaken in Poland in 2015 under the ESPAD project upon commission of the National Bureau for Drug Prevention (KBPN) and

Address for correspondence: Piotr Jabłoński, Dereniowa 52/54, 02-776 Warsaw Poland

E-mail: piotr.jablonski@kbpn.gov.pl

Received: 01 September 2016; accepted: 14 September 2016
State Agency for Prevention of Alcohol-related Problems (PARPA) [2]. The study was conducted on a representative sample of $3^{\text {rd }}$ grade students of upper-primary schools and $2^{\text {nd }}$ grade students of secondary schools. The data collected demonstrate that the most prevalent illicit substances among youth include marijuana and hashish (Tab. 1 and 2). The results of the research have been presented by means of the last-12-months indicator, which reflects best the current prevalence of substance use among young people.

Table 1. Percentages of students aged 15-16 who have used the respective substance in the last 12 months - results of ESPAD study

\begin{tabular}{lcccccc}
\hline Substance & $\mathbf{1 9 9 5}$ & $\mathbf{1 9 9 9}$ & $\mathbf{2 0 0 3}$ & $\mathbf{2 0 0 7}$ & $\mathbf{2 0 1 1}$ & $\mathbf{2 0 1 5}$ \\
\hline Marijuana, hashish & $7 \%$ & $12 \%$ & $15 \%$ & $11 \%$ & $20 \%$ & $19 \%$ \\
\hline Inhalants & $4 \%$ & $4 \%$ & $4 \%$ & $4 \%$ & $5 \%$ & $6 \%$ \\
\hline Ecstasy & - & - & $2 \%$ & $1 \%$ & $2 \%$ & $3 \%$ \\
\hline
\end{tabular}

Source: Institute of Psychiatry and Neurology, ESPAD 2015

Table 2. Percentages of students aged 17-18 who have used the respective substances in the last 12 months - results of ESPAD study

\begin{tabular}{lcccccc}
\hline Substance & $\mathbf{1 9 9 5}$ & $\mathbf{1 9 9 9}$ & $\mathbf{2 0 0 3}$ & $\mathbf{2 0 0 7}$ & $\mathbf{2 0 1 1}$ & $\mathbf{2 0 1 5}$ \\
\hline Marijuana, hashish & $10 \%$ & $17 \%$ & $26 \%$ & $17 \%$ & $29 \%$ & $32 \%$ \\
\hline Inhalants & $3 \%$ & $2 \%$ & $2 \%$ & $3 \%$ & $2 \%$ & $2 \%$ \\
\hline Ecstasy & - & - & $4 \%$ & $3 \%$ & $3 \%$ & $2 \%$ \\
\hline
\end{tabular}

Source: Institute of Psychiatry and Neurology, ESPAD 2015

$19 \%$ of the younger students and $32 \%$ of the older ones reported using cannabis in the last 12 months in 2015. 
Compared to the relatively high rise in 2011, recently a slight decrease has been observed in the younger age group while a 3-percentage-point increase was recorded among the older students.

In the case of the remaining drugs, no major differences between the surveys of 2007, 2011 and 2015 have been noticed.

Another source of information on the prevalence of drug use among school youth are the results of the research project entitled 'Consumption of psychoactive substance in school youth - Youth 2013', which was conducted in 2013 by the CBOS Foundation in collaboration with the National Bureau for Drug Prevention [3]. The survey included a nationwide sample of 1,360 school-age students aged 18-19. The results have also been presented by means of the last 12 months prevalence rate as the best option for reflecting the current prevalence of the abovementioned substances among youth.

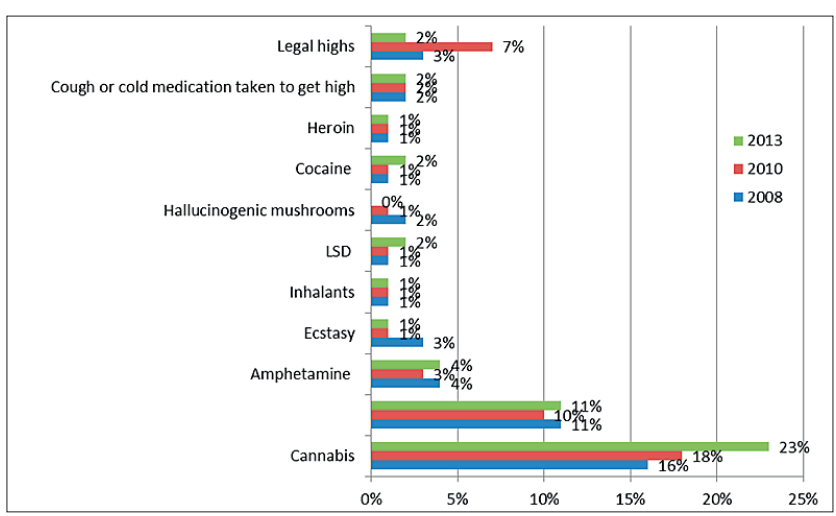

Figure 1. Percentages of students aged 18-19 who have used the respective substances in the last 12 months - results of Youth survey. Source: CBOS Foundation - Youth 2013

The results of the 2013 survey remained similar to the results of the 2010 research. The exception is cannabis, which rose compared to the previous study. In 2013, the cannabis prevalence rate for the last 12 months stood at $23 \%$ (compared to $18 \%$ in 2010 ).

Drug market and drug-related crime. According to the European Monitoring Centres for Drugs and Drug Addiction (EMCDDA), cannabis ranked first in terms of the number and volume of drug seizures. The latest EMCDDA Drug Report reveals that in the EU in 2014, 453,000 seizures of marijuana and 229,000 seizures of hashish were recorded. In total, 139 tons of marijuana and 574 tons of hashish were seized. Compared to the previous years, marijuana indicators are constantly rising [1]. The authors of the report note that highly potent marijuana (high concentration of THC and low concentration of CBD) is becoming increasingly prevalent.

Cannabis ranks first in terms of drug-related crime. In the EU, of the 1.6 million recorded crimes, $57 \%$ were related to cannabis. Possession of cannabis constituted the widest share in the above-mentioned crimes (75\% of all drug possession crimes).

Drug treatment and medical emergencies. The above-cited EMCDDA report shows an upward trend in the case of individuals reporting for cannabis treatment for the first time in Europe, as well as indicating changes in the patterns of cannabis use. The overall number of first-time cannabis patients rose from 45,000 in 2006 to 69,000 in 2014, while the number of daily cannabis users increased in this period from $46 \%$ to $54 \%$. In Poland, of all the first-time drug patients in $2014,44.6 \%$ were cannabis users.

The data of the European Drug Emergencies Network (Euro-DEN) point to cannabis use as the third in terms of the number of medical emergencies. In 2014 in Europe, 16\% of a total of 5,409 medical interventions were conducted in relation to cannabis use. For comparison, $24 \%$ of the interventions were heroin related and $17 \%$ cocaine related. A steady growth in the number of medical emergencies in connection with cannabis has also been recorded e.g. in Spain.

According to the authors of the EMCDDA report, 'Potency of both hashish and marijuana is high above average, which is alarming as it might expose users to a higher risk of acute and chronic health problems'.

Likely use of cannabis for medical purposes. Cannabinoids are considered effective in patients suffering from somatic diseases such as chronic pain (related to e.g. cancer or in terminally-ill patients), respiratory system disorders (asthma), eye disorders (glaucoma) or multiple sclerosis. Clinically, the most convincing results of using cannabinoids are found in providing relief for patients suffering from high muscle tone, adverse effects of chemotherapy (e.g. nausea) or support in AIDS treatment [4]. In most cases, there is research to corroborate the likely effectiveness of cannabis in treating the above-mentioned diseases and related symptoms; however, the results of such studies raise many doubts due to the low numbers of analysed cases or other methodological limitations. That is why the effectiveness of using cannabis to treat the above-mentioned disorders has not been fully proved. As Metts notes: 'While many claims have been made about the therapeutic effects of marijuana, only a few of these claims have evidence to back them up' [5].

Discussion of the medical use of cannabis. The use of cannabis for medical purposes is being widely discussed all over the world. It has its supporters and opponents. It also divides the scientific community. Undoubtedly, there are a number of studies which provide promising results as to the effectiveness of cannabis-based treatment. However, there also exists a comparable number of research projects which prove otherwise. Each of these studies has its methodological limitation, has been conducted on an insufficient sample, has been based on false assumptions or indicates only the potential effectiveness of medical cannabis. As Prof. Mazurkiewicz-Bledzinska of the Developmental Neurology Clinic of the Medical University of Gdansk states: 'We have no data at hand to prove that cannabis has therapeutic qualities and vice versa - there is no proof that such qualities do not exist' [6]. In her statement, Prof. Bedzinska emphasises the important issues raised in the public debate: 'In my opinion, in the case of the so-called medical cannabis, we deal with a paradoxical situation according to which, with the help of youth, public consent for cannabis for adults is being sought. If it involves groups lobbying for cannabis, then we are in two different places. We talk of using cannabis for therapeutic purposes while it has nothing to do with legalizing the drug'. Dr Habrat of the Institute of Psychiatry and Neurology in Warsaw presents the problem in a similar fashion: 'It is far more interesting to see the extra-medical functioning of the 
results of scientific research. It seems that positive results are of little clinical value while they play a major role to improve the image of all the issues related to cannabis use' [7]. Dr Habrat also points to potential adverse effects of the illconceived introduction of wide access to medical cannabis: 'The best example are the social processes in some states of the US, where the results of scientific research have not translated into a better access for sick individuals to products containing carefully clinically selected and pharmaceutically pure cannabinoids which would be properly dosed. Instead, they led to an easy access to cannabis without medical indications, with no control of either dosage or time of use and without the monitoring of adverse effects'. However, the possibility of using cannabis for medical purposes cannot be questioned with $100 \%$ certainty. This position has been adopted by the majority of national and international organizations concerned with public health. On the one hand, the World Health Organization places emphasis on the harm which might be caused by the abuse or addiction to cannabis; on the other hand, it supports the claim of the therapeutic effects of some cannabinoids, as reported in several controlled studies. The WHO is aware of the legal status of cannabinoids (illegality of the drug under the UN Convention of 1961); however, from the medical point of view it recognizes that research in this field should be continued.

Consequences of the introduction of cannabis to treatment. At least several European countries and some states of the USA have decided to allow cannabis for medical purposes. However, various distributions models have been adopted. Apart from the therapeutic issues, attempts have been made to evaluate the way these changes affected the consumption of cannabis in society at large. These studies fail to provide a clear answer. Cerda and colleagues [8] analysed results of US general population surveys by comparing the scale of use, abuse and addiction to cannabis in states which had allowed for the medical use of the drug with the states which had decided against. The results of the analysis revealed higher percentages of active and addicted cannabis users in the states where medical cannabis was legal, compared to the states where the drug remained illegal. However, the differences have not been observed in the period of the last 12 months. This might imply that the states which made medical cannabis legal had seen higher prevalence rates of cannabis use before the changes. Still, one cannot preclude the fact the introduction of such legal solutions might contribute to the rise in the consumption by changing social norms concerning the perceived safety and consent for cannabis use, but this thesis should be further explored scientifically.

Some analyses suggest that that impact of the legalization of medical cannabis on the scale of non-medical use of cannabis in society depends on detailed regulations. This issue was the subject of a research project conducted in the United States in 2015 [9]. The law in the United States in this field provides for a number of detailed regulations in the respective states such as running a register of individuals treated with 'medical' cannabis; a homemade cannabis cultivation permit, sales of cannabis in designated outlets - so-called 'dispensaries'. The analysed cannabis use data were taken from the Treatment Episode Data Set (TEDS) for the years 1992-2011, as well as the National Longitudinal Survey of Youth for the years 1997-2011. The analyses showed that in the states which allowed dispensaries, compared to the states which did not implement such a solution, there is a higher risk of a rise in medical cannabis prevalence and the related negative consequences.

The legalization of medical cannabis might result in the 'leakage' of the substance into the illegal market and consequently in the use of medical cannabis for non-medical purposes. Szulc, while analysing the health consequences of using cannabis, as well as the position of psychologists on the legalization of cannabis, pointed to the paper by Salomonsen-Sautel et al., who proved that $74 \%$ of teenagers in the United States have used someone else's medical cannabis [10].

All in all, the discussion of the medical use of cannabis should include the potential impact of such a solution on the scale of extra-medical use of cannabis in society. It should be carefully considered in view of the fact that the demand for cannabis in Polish society is equally as high as in the other European countries, as corroborated by research. This might lead to the situation where the treatment system sponsors the non-medical use of the drug.

\section{CONCLUSIONS}

This analysis shows that the rushed introduction of a wide and universal access to medical cannabis might negatively impact on the health of the public. It does not change the fact that research into the application of cannabis for therapeutic purposes should be continued (also in the form of experimental therapy). This solution seems to be helpful in conducting a number of supportive treatments. However, it is of crucial importance to separate, in the public debate, the question of medical cannabis from the 'warming-up of the public image' of this substance and discussion of the liberalization of the drug law in relation to cannabis. The only criterion for applying cannabis in medical treatment should be its effectiveness, and the availability procedures should not differ from the procedures used to allow trade in other pharmaceuticals. The discussion of the use of cannabis for medical purposes should be left to physicians and the legality issues should not in any way affect the assessment of the therapeutic effects of this substance.

\section{REFERENCES}

1. European Monitoring Centre for Drugs and Drug Addiction. European Drug Report 2016: Trends and achievements pp. 19, 33, 38-39, 75, Publications Office of the European Union, Luxembourg; 2016.

2. Sierosławski J. Używanie substancji psychoaktywnych przez młodzież szkolną Województwa Wielkopolskiego. Badanie ankietowe (ESPAD), Warszawa 2015 [The use of psychoactive substances by school students of the Wielkopolska Region. The survey (ESPAD), Warsaw 2015] (in Polish).

3. Malczewski A. Młodzież a substancje psychoaktywne w Młodzież 2013, Fundacja Centrum Badania Opinii Społecznej, Warszawa 2014 [Young people and psychoactive substances in the Youth 2013 Foundation Center for Public Opinion Research, Warsaw; 2014] (in Polish).

4. Jablonski P. Medyczne używanie konopi [Medical use of cannabis]. Serwis Informacyjny Narkomania 2015; 3(71) (on Polish).

5. Metts J, et el. Medical marijuana: A treatment worth trying. J Fam Pract. 2016; 65(3): 178-185.

6. Kielar M. Marihuana na ziemi niczyjej [Marijuana no man's land]. Służba zdr. 2015; (4494-4501): 56-59.

7. Habrat. Marihuana, jej preparaty farmaceutyczne i ich analogi w zastosowaniu medycznym [Marijuana, the pharmaceutical preparations and their analogues in the application of medical, pharmacology of 
cannabinoids]. Farmakologia kannabinoidów, XXXII szkoła zimowa Instytutu Farmakologii PAN 2015, Kraków (in Polish).

8. Cerda M, Wall M, Keyes KM, Galea S, Hasin D. Medical marijuana laws in 50 states: Investigating the relationship between state legalization of medical marijuana and marijuana use, abuse and dependence. Drug Alcohol Depend. 2012; 120(1-3): 22-27.

9. Pacula R, Powell D, Heaton P, Sevigny E. Assesing the effects of medical marijuana laws on marijuana use: the devil is in the details, www.ncbi. nlm.nih.gov/pubmed/25558490 dated 08/24/2016
10. Szulc M. Konsekwencje zdrowotne używania marihuany w świetle badań oraz propozycja ujednolicenia stanowiska psychologów wobec problemu legalizacji konopi, sformułowana w oparciu o Kodeks Etyczno-Zawodowy Psychologa [The health consequences of marijuana use in the light of research and the proposal standardize the position of psychologists to the problem of the legalization of cannabis, formulated on the basis of the Code of Ethics and Professional Psychologists]. Alkoholizm i Narkomania 2013; 26(4): 381-401 (in Polish). 